\title{
INGKAR SUNNAH DALAM SOROTAN IMAM SYAFI'I
}

\author{
Oleh: Junaid Bin Junaid
}

\begin{abstract}
Sunnah is the second source of Islamic teachings after the Qur'an. Because the sunnah provides an explanation of the generality of one verse of the Qur'an which has a global meaning, so the meaning is clear. In this case, as one parcel of the generality. It's just that, the sunnah as a source of Islamic law there are still understandings or groups who reject it as one of the foundations or sources of Islamic law. And one of the ideas that reject the sunnah as a source of Islamic teachings or law is to understand the renegade of the sunnah. Where this understanding states that the Qur'an is the main and only source. All issues relating to the hablun min Allah and hablun min annas are all clearly illustrated in the Qur'an, so that the sunnah cannot be used as a source or basis. And according to the Shafi'ite Imama that it turns out that there is still a renegade understanding that there are moderate thoughts that can accept the sunnah as a foundation in Islamic law. That is still using the sunnah but the sunnah is valuable mut mutha who have many narrators and it is impossible to do lies in an action or deed.
\end{abstract}

\section{Kata Kunci: Sunnah, Ingkar Sunnah, Imam Syafi’i}

\section{I.PENDAHULUAN}

Nabi Muhammd saw sebagai mubayyin Al-Qur'an dan musyarri', menempati posisi yang penting dalam agama Islam. Selain dua hal tersebut, nabi berfungsi sebagai suri tauladan bagi umatnya. Dalam rangka itulah apa yang dikatan, diperbuat, dan ditetapkan oleh nabi Muhammad saw dikenal dengan istilah sunnah yang di dalam ajaran Islam sebagai salah satu sumber atau pedoman bagi umat Islam. ${ }^{1}$ Dan perjalan sejarahnya meniscayakan adanya pergeseran tentang pemahaman masyarakat tentang posisi sunnah sebagai penjelas daripada Al-Qur'an itu sendiri.

Sunnah bagi umat Islam secara keseluruhan adalah hal yang sangat urgent untuk senantiasa dan selalu dijadikan landasan sebagai satu pedoman hidup. Karena di dalamnya memuat tentang hal-hal yang berkiatan dengan segala hal-ihwal yang telah dilakukan oleh nabi saw sejak awal keRasulannya. Dalam hal ini, perbuatan-perbuatan yang dilakukan oleh nabi saw sebagai

${ }^{1}$ M. Alfatih Suraydilaga, Aplikasi Penelitian Hadis Dari Teks ke Konteks (Cet. I; Yogyakarta: Kalimedia, 2016), h. 1. 
sebuah cermin dari masa ke masa tentang mengakualisasikan sunnah sebagai sumber ajaran atau hukum Islam yang kedua setelah Al-Qur'an.

Sunnah nabi adalah metode terperinci bagi kehidupan muslim, baik sebagai individu atau sebagai anggota masyarakat. Sunnah adalah penjelas atas Al-Qur'an dan realisasi Islam. Karena Rasulullah saw adalah yang menjelaskan Al-Qur'an dan yang merealisasikan Islam, dengan ucapan dan perbuatan, dan seluruh kehidupannya pada saat sendirian maupun saaat bersosialisasi, ketika sedang menetap maupun bepergian, ketika bangun maupun tidur, kehidupan pribadi maupun umum, hubungan Allah dan manusia, bersama kerabat dekat maupun jauh, dengan teman atau musuh, dalam keadaan damai maupun perang, ketika sehat maupun sakit. ${ }^{2}$

Kedudukan sunnah dalam pembinaan syariat Islam dan pengaruhnya dalam kehidupan kaum muslimin dari mulai Rasulullah saw, para sahabatnya, tabiin, tabi' tabiin sampai zaman sekarang ini dan sampai hari kiamat merupakan suatu kenyataan yang diterima sebagai kebenaran yang tidak dapat diragukan dan tidak perlu dibuktikan lagi. Barang siapa yang menelaah AlQur'an dan sunnah, niscaya akan menemukan tentang besarnya pengaruh sunnah dalam pembinaan syariat Islam dan keagungan serta keabadiannya yang tidak mungkin diingkari oleh pakar-pakar sunnah. ${ }^{3}$

Dengan demikian, bahwasanya sunnah nabi saw memberikan sebuah keteladanan secara baik dan universal dalam berbagai macam ilmu pengetahuan. Sunah juga merupakan sumber berbagai aspek kehidupan manusia yang relevan dengan zama dan tempat. Sunnah kaya dengan konsepkonsep ilmu pengetahuan yang masih belum diungkap oeh umumnya umat Islam. ${ }^{4}$ Dan hal ini merupakan acuran dan landasan untuk menghindari terjadinya kesalah pahaman terhadap sunnah nabi saw. Seperti apa yang terdapat dalam pemahaman ingkar sunnah yang kurang memahami sunnah secara menyeluruh, sehingga kelompok ingkar sunnah ini menganggap bahwa hanya satu sumber saja dalam ajaran Islam, yaitu Al-Qur'an.

Dengan hadirnya Imam Syafi'i yang memiliki kecerdasan yang luas dan memiliki masa kehidupan atau lingkngan hidup yang berhadapan langsung dengan kelompok atau paham ingkar sunnah, tentunya Imam Syaif'i memiliki pendapat yang objektif dan dapat dipertanggung jawabkan tentang paham ingkar sunnah tersebut. Dalam hal ini, ternyata ingkar sunnah tersebut secara sejarah, tidak semua orang atau anggota yang mempunyai paham atau pemahaman terhadapnya mempunyai penolakan terhadap sunnah secara menyeluruh, tetapi tetap ada yang menerima sunnah yang tidak bertentangan dengan Al-Qur'an.

${ }^{2}$ Yusuf Qordhowi, Al-Madkhal li Dirasah As-Sunnah Al-Nabawiyyah, diterjemahkan oleh Agus Suyadi Raharusun dan Dede Rodin, dengan judul Pengantar Studi Hadis (Cet. I; Bandung: Pustaka Setia, 2007), h. 128.

${ }^{3}$ Yazid bin Abdul Qadir Jawas, Kedudukan As-Sunnah Dalam Syariat Islam (Cet. 6; Bogor: Pustaka At-Taqwa, 2015), h.19.

4 Abdul Majid Khon, Hadis Tarbawi; Hadis-Hadis Pendidikan (Cwt. I; Jakarta: Kencana Prenada Media Group. 2012), h. v. 


\section{II.PEMBAHASAN}

\section{A.Terminologi Ingkar Sunnah dan Pokok Ajarannya}

Secara etimologi, kata ingkar sunnah terdiri dari dua kata, yaitu ingkar dan sunnah. Kata "ingkar" berasal dari akar kata bahasa Arab: Ankara, yunkiru, inkaran yang mempunyai beberapa arti, di antaranya; tidak mengakuai dan tidak menerima baik di lisan dan di hati, bodoh atau tidak mengetahui sesuatu (antonim kata al-irfan, dan menolak apa yang tidak tergambarkan dalam hati,",

Dalam pandangan Al-Askari, beliau membedakan antara makna $\mathrm{Al}$ Inkar dan Al-Juhdu. Kata Al-Inkar terhadap sesuatu yang tersembunyi dan tidak disertai pengetahuan, sedangkan Al-Juhdu terhadap sesuatu yang tampak dan disertai dengan pengetahuan. Dengan demikian, bisa jadi orang yang mengingkari sunnah sebagai hujah di kalangan orang yang tidak banyak pengetahuannya tentang ulum hadis.

Dengan berlandaskan dari beberapa arti kata ingkar di atas dapat disimpulkan bahwa ingkar secara etimologis diartikan menolak, tidak mengakui, dan tidak menerima sesuatu, baik lahir dan batin atau lisan dan hati yang dilatarbelakangi oleh keyakinan, dan lain-lain. Sedangkan kata sunnah adalah jalan yang dilalui orang-orang dahulu kemudian diikuti oleh orangorang belakangan, tata cara dan tingkah atau perilaku hidup, baik perilaku itu terpuji maupun tercela, juga dapat berarti tata cara, baik maupun buruk. ${ }^{6}$

Orang yang menolak sunnah sebagai hujah dalam beragama oleh umumnya ahli hadis disebuat ahli bid'ah dan menuruti hawa nafsu. Mereka ahli bid'ah yang mengikuti kemauan hawa nafsu, bukan kemauan hati dan akal pikirannya. Mereka itu, kaum Khawarij, Mu’tazilah, dan lain-lain, karena mereka itu umumnya menolak sunnah. Gelar ini diberikan kepada mereka yang menempati sekte-sekte tersebut, karena mereka ber-istinbath, membela dan mempertahankan untuk hawa nafsu. Sebagaimana ahli sunnah sebagai penolog sunnah dan pembelanya, ber-istinbath sesuai dengan sunnah.

Sedangkan pengertian ingkar sunnah secara terminology, ada beberapa definisi ingkar sunnah yang sifatnya masih sangat sederhana pembatasnya, di antaranya sebagai berikut:

1. Paham yang timbul dalam masyarakat Islam yang menolak hadis atau sunnah sebagai sumber ajaran agama Islam kedua setelah Al-Qur'an. ${ }^{7}$

2. Suatu paham yang timbul pada sebagian minoritas umat Islam yang menolak dasar hukum Islam dari sunnah shahih, baik sunnah praktis atau yang secara formal dikodifikasikan para ulama, baik secara totalitas mutawatir maupun ahad atau sebagian saja, tanpa ada alasan yang dapat diterima. ${ }^{8}$

${ }^{5}$ Ibrahim Anis, Al-Mu'jan Al-Wasith, Juz. 3 (Mesir: Darul Ma'arif, 1972), h. 951.

${ }^{6}$ Mohammad Nor Ichwan, Studi Ilmu Hadis (Cet. I; Semarang: Rasail, 2007), h. 5.

7 TIM IAIN Syarif Hidayatullah, Ensiklopedi Islam Indonesia (Cet. I; Jakarta: Djambatan 1992), h. 428. 2000), h. 58.

8 Abdul Majid Khon, Pemikiran Ingkar Sunnah (Cet. I; Jakarta: Bulan Bintang, 
Bahwasanya definisi kedua lebih rasional yang mengakumulasi berbagai macam ingkar sunnah yang terjadi di sebagian masyarakat belakangan ini terutama, sedang definisi sebelumnya tidak mungkin terjadi karena tidak ada atau tidak mungkin seorang muslim mengingkari sunnah sebagai dasar hukum Islam. Maka dari itu, dari definisi tentang makna ingkar sunnah secara terminology, dapat dipahami bahwa ingkar sunnah adalah paham atau pendapat perorangan atau paham kelompok, bukan gerakan atau aliran, ada kemungkinan paham ini dapat menerima sunnah selain sebagai sumber hukum Islam, misalnya sebagai fakta sejarah, budaya, tradisi, dan lainlain. Sunnah yang diingkari adalah sunnah yang shahih, baik secara substansial, yaitu sunnah praktis pengalaman Al-Qur'an (sunnah 'amaliyah) atau sunnah formal yang dikodifikasikan para ulama meliputi perbuatan, perkataan, dan persetujuan Nabi. Bisa jadi mereka menerima sunnah secara substansial, tetapi menolak sunnah formal atau menolak seluruhnya.

Paham ingkar sunnah bisa jadi menolak keseluruhan sunnah, baik sunnah mutawatirah dan ahad atau menolak yang ahad saja dan atau sebagian saja. Demikian juga penolokan sunnah tidak didasari alasan yang kuat, jika dengan alasan yang dapat diterima oleh akal yang sehat, seperti seorang mujtahid yang menemukan dalil yang lebih kuat daripada hadis yang ia dapatkan, atau hadis itu tidak sampai kepadanya, atau karena kedha'ifannya, atau karena ada tujuan syar'i yang lain, maka tidak digolongkan ingkar sunnah.

Dalam hubungannya dengan kritik sanad, bagi kelompok ingkar sunnah bahwa hal itu sangat lemah untuk menentukan kesahihan hadis dengan alasan bahwa dasar kritik sanad itu yang dalam kajian ulumul hadis dikenal dengan istilah ilmu jarh wa ta'dil (ilmu yang membahas ketercelaan dan keterpujian para periwayat hadis), baru muncul setelah satu setengah abad nabi wafat. Dengan demikian, para periwayat generasi sahabat nabi, tabiin dan tabi' tabiin tidak dapt ditemui dan diperiksa lagi. Dan juga seluruh sahabat nabi sebagai periwayat hadis pada generasi pertama dinilai adil oleh ulama hadis pada akhir abad ketiga dan awal abad keempat hijriah. Denga konsep ta'dil al sahabah, para sahabat dinilai terlepas dari kesalahan dalam melaporkan hadis. ${ }^{9}$

Untuk memahami lebih detail tentang ingkar sunnah tersebut, maka perlu pula mengetahui pokok-pokok ajaran yang ada dalam paham ingkar sunnah tersebut. Di anatara pokok-pokok ajaran yang dimaksud adalah; 1). Tidak percaya kepada semua hadis Rasulullah saw. Menurut mereka hadis itu karangan Yahudi untuk menghancurkan Islam dari dalam. 2). Dasar hokum Islam hanya Al-Qur'an saja. 3). Syahadat mereka isyhadu bianna muslimun. 4). Shalat mereka bermacam-macam, ada yang shalatnya dua rakaat-dua rakaat dan ada yang hanya eling saja (ingat). 5). Puasa wajib hanya bagi orang yang melihat bulan saja, kalau seorang saja yang melihat bulan, maka dialah yang wajib berpuasa. 6). Haji boleh dilakukan selama empat bulan haram, yaitu; muharram, rajab, zulqaidah, dan zulhijjah. 7). Pakaian ihram adalah pakaian arab dan membuat repot. Oleh karena itu , waktu mengerjakan haji boleh

${ }^{9}$ M. Syuhudi Ismail, Hadis Nabi Menurut Pembela Penginkgar dan Pemalsuannya (Cet. I; Jakarta: Gema Inani Press, 1995), h. 21. 
memakai celana panjang dan baju biasa serta memakai jas/dasi. 8). Rasul tetap diutus sampai hari kiamat. 9). Nabi Muhammad tidak berhak menjelaskan tentang ajaran Al-Qur'an (kandungan isi Al-Qur'an). 10). Orang yang meninggal dunia tidak dishalati karena tidak ada perintah Al-Qur'an. ${ }^{10}$

Dari pokok ajaran tersebut yang dianut dan diyakini oleh kelompok atau paham ingkar sunnah menandakan tidak menjadikan sunnah sebagai sumber syariat Islam san hanya berpedoman dan berlandaskan pada Al-Qur'an semata sebagai sumber dalam kehidupan sehari-hari.

\section{B.Imam Syafi’i dan Ingkar Sunnah}

\section{a.Biografi Imam Syafi'i}

Nama lengkapnya adalah Abu Abdillah Muhammad bin Idris al'Abbas bin Usman bin Syafi'i bin as-Sa'id bin Abdi Yazid bin Hisyam bin alMutalib. ${ }^{11}$ Ia dilahirkan pada $150 \mathrm{H}$ bersamaan dengan kemangkatan Abu Hanifah di Ghazzah yang masih termasuk wilayah Syam (Palestina) dan meninggal dunia di Mesir pada malam Jum'at tanggal 29 Rajab tahun 204 H./ 19 Junuari 820 M. Ketika baru berusia dua tahun, ayahnya meninggal di Ghazzah, dan kemudian ia dibawa oleh ibunya ke Mekah untuk belajar alQur'an dan berhasil menghapalkannya pada usia 9 tahun.

Selanjutnya, as-Syafi'i belajar fikih pada Muslim bin Khalid az-Zanji dan Sa'id bin Salim serta ulama besar Mekah lainnya. Pada usia 10 tahun, asSyafi'i sudah pula menghapal kitab Muwattha' Imam Malik yang diperolehnya dari pinjaman temannya. Pada usia 15 tahun telah dipercaya oleh gurunya Muslim az-Zanji untuk menjadi mufti di Mekah. Kemudian, as-Syafi'i pindah ke Madinah dan belajar ke Imam Malik bin Anas untuk mentshih hapalan Muwattha'-nya. Selain itu, as-Syafi'i juga belajar berbagai ilmu lain, seperti kususastraan pada kalangan Huzail. ${ }^{12}$

Sebenarnya, as-Syafi'i lebih populer sebagai faqih dibanding sebagai muhaddits. Berbagai karyanya yang terkenal banyak memuat pembahasan fikih dengan segala kaitannya, seperti al-Umm dan al-Kitab, yang dikenal kemudian dengan ar-Risalah setelah dikirimkan ke Abd Rahman bin Mahdi.

Imam Syafi'i tidak pernah menulis secara khusus tentang hadis, beberapa kitab yang dikaitkan dengan namanya seperti Musnad as-Syafi'i riwayat Abu al-Abbas al-Asham dan Sunan as-Syafi'i riwayat at-Thahawi, kesemuanya diperkirakan merupakan resensi oleh para muridnya dan bukan oleh as-Syafi'i sendiri, perihalnya sama dengan masanid Abu Hanifah. Namun demikian, tidak berarti as-Syafi'i kurang menguasai ataupun kurang perhatian terhadap hadis. Sebagai imam mazhab yang dijuluki Nashir as-Sunnah (Pembela Sunnah) terkenal sebagai orang yang sangat teguh dalam menempatkan hadis sebagai sumber utama setelah Al-Qur'an dalam setiap

\footnotetext{
${ }^{10}$ Abdul Majid Khon, Ulumul Hadis (Cet. 4: Jakarta: Amzah, 2016), h.40.
}

11 Ahmad Muhammad Syakir, Al-Risalah lil Imam Muhammad Idris al-Syafi'I (Beirut: Darul Kutub al-Ilmiyah, t.th.), h. 1. h.194.

${ }^{12}$ M. Alfatih Suryadilaga dkk, Ulumul Hadis (Cet. I; Yogayakarta: Kalimedia, 2015), 
penetapan hukumnya. Berbagai riwayat telah mengukuhkan hal tersebut, antara lain pernyataan: "Jika kalian menjumpai dalam kitab saya sesuatu (pendapat) yang berbeda atau bertentangan dengan sunnah Rasulullah saw maka ambillah sunnah Nabi dan jauhi pendapatku."

Kurangnya data mengenai keterlibatan Imam Syafi'i dalamm hadis dengan lingkup luas dan khas disebabkan antara lain bahwa Imam Syafi'i tidak mengadakan kuliah (majilis ta'lim) yang khusus untuk mengajarkan hadis dan periwayatannya sebagaimana halnya yang bisa dilakukan oleh muhaddits. Pembahasan dan penelitian hadis yang dilakukan hanya seputar hadis yang dapat dijadikan sebagai dasar bagi istinbath tasyri' $i$ sesuai dengan kapasitasnya sebagai imam mujtahid dalam bidang fikih. Adapun dasar istinbath yang kemudian menjadi dasar mazhabnya adalah: "Dalil yang pokok atau utama adalah al-Qur'an dan sunnah; bila tidak ada di dalam keduanya maka gunakanlah qiyas (analog). Hadis yang sambung sanadnya pada Rasul maka sah sanadnya.

Disamping itupula, Imam Syafi'i mendebat pendapat-pendapat ulama Irak tanpa menyinggung kehormatan orang-orang yang didebatnya, sehingga Ahmad bin Hanbal berkata; al-Syafi'i adalah seorang filosof dalam empat hal; dalam bahasa, dalam perbedaan pendapat, dalam segi makna dan dalam fikih. Dalam perdebatan-perdebatannya ia sangat membela hadis dan ulamaulamanya. Ia sangat ahli dalam berdebat dan mengetahui uslub-uslubnya. ${ }^{13}$

Tampak sekali, bahwa Imam Syafi'i merupakan seorang ulama yang memiliki kecerdasan handal dan menyeluruh dalam berbagai macam disiplin ilmu pengetahuan. Salah satunya adalah kegigihan beliau yang mempertahankan sunnah sebagai bayan daripada Al-Qur'an sebagai sumber pertama dan utama dalam ajaran Islam.

\section{b.Imam Syafi'i dan Ingkar Sunnah}

Kedudukan hadis, terutama sebagai sumber hukum Islam, sejak zaman yang masih dini sudah dipersoalkan. Imam Syafi'i, yang digelari Nasir al-Hadis (Pembela Hadis), pernah menyebutkan adanya pendapat yang menolak hadis. Dengan kata lain, paling sedikit, ada pendapat yang menerima hadis yang hanya semakna dengan Al-Qur'an, yaitu hadis mutawatir. Sedangkan selain hadis-hadis mutawatir mereka enggan mengamalkannya atau bahkan menolak dengan dalih bahwa Al-Qur'an sudah cukup sebagai sumber yang bersifat universal dan umum. Karena itu, pernyataan bahwa umat Islam sejak zaman dahulu sampai sekarang telah sepakat menerima hadis sebagai salah satu sumber hukum Islam sesudah Al-Qur'an harus diberi catatan karena di kalangan ulama Islam juga ada yang tidak sependirian dengan kesepakatan tersebut, yang biasanya disebut ulama Ahlu Ra'yi (penganut pendapat), tidak menerima suatu hadis sebelum mengemukakan keterangan-keterangan Al-Qur'an yang muhkam (tidak memerlukan lagi penjelasan apa-apa). Tentu saja pendirian serupa ini tidak dapat dinilai sebagai tidak berharga karena ia lahir dari ulama-ulama kalangan Islam sendiri, bukan di luarnya.

\footnotetext{
${ }^{13}$ M. Alfatih Suryadilaga. Edt., Studi Kitab Hadis (Cet. I; Yogyakarta: Teras, 2003),
} h. 291. 
Kedatangan Imam Syafi'i ke Bagdadpada tahun $184 \mathrm{H}$, yaitu ketika Imam syafi'i berumur 34 tahun. Kiranya penderitaan yang amat pahit yang dirasakannya inilah yang menyebabkan ia melepaskan jabatan pemerintahan dan menekuni bidang keilmuan, sehingga dapat mewariskan pusaka yang kekal sepanjang masa. Selama di Bagdad ia mempelajari fikih Irak, ia membaca kitab-kitab Muhammad bin Hasan. Dengan demikian berkumpullah padanya fikih hijazi dan fikih iraki., atau fikih yang berpegang pada dirayah. Walaupun Imam Syafi'i menghadiri majelis ibnu Hasan, tetapi ia memandang dirinya sebagai pengikuti setia Imam Malik, salah seorang pengikut mazhabnya dan salah seorang penghafal muwatta', sehingga ia tetap membela fikih madinah. Oleh karenanya ia sering mendebat Muhammad bin Hasan karena menganggap sebagai guru. Akan tetapi pada akhirnya ia juga sempat berdiskusi dan mendebatnya karena atas permintaan Muhammad bin Hasan sendiri. ${ }^{14}$

Ingkar sunnah sebagai paham atau kelompok yang menolak sunah atau hadis Rasulullah SAW schagai hujah dan sumber kedua ajaran Islam yang wajib ditaati dan diamalkan. Imam Syafi'i menyatakan bahwa kelompok ini muncul di penghujung abad kedua atau awal abad ketiga Hijriah.

Orang-orang inkarsunah sebenarnya terdiri dari tiga kelompok dengan tiga sikap yang berbeda. Kelompok pertama adalah kelompok yang menolak hadis-hadis Rasulullah SAW sebagai hujah secara keseluruhan. Argumentasi kelompok perta- ma ini dalam menolak hadis sebagai sumber kedua ajaran Islam adalah sebagai berikut:

(1) Al-Qur'an diturunkan Allah SWT dalam bahasa Arab. Dengan penguasaan bahasa Arab yang baik, maka Al-Qur'an akan dapat dipahami dengan baik, tanpa memerlukan bantuan penjelasan dari hadis-ha-dis Rasulullah SAW;

(2) Al-Qur'an, sebagaimana disebutkan Allah SWT, adalah penjelas segala sesuatu (QS 16:89) Hal ini mengandung arti bahwa penjelasan Al-Qur'an telah mencakup segala sesuatu yang dipcrlukan oleh umat manusia. Dengan demikian maka tidak perlu lagi penjelasan lain selain Al-Qur'an,

(3) hadis-hadis Rasulullah SAW sampai kepada kita melalui suatu proses periwayat- an yang tidak dijamin bersih dari kekeliruan, kesa- lahan, dan balkan kedustaan terhadap Rasulullah SAW Oleh karena itu nilai kebenarannya tidak meyakinkan (ranni). Karena status ke-zanni-an ini, maka hadis tersebut tidak dapat dijadikan sebagai penjelas (mubayyin) bags AlQur'an yang diyakini kebenarannya (qat'i).

Dari ketiga argumentasi ini mereka menolak otoritas hadis-hadis Rasulullah SAW sebagai hujah dan sumber kedua ajaran Islam. Dengan demikian, dalam prinsip mereka sunah tidak perlu ditaati dan diamalkan. Sumber satu-satunya ajaran Islam bagi mereka adalah Al-Qur'an. Imam Syafi'i memberikan jawaban atas argumen-argumen kelompok inkarsunah tersebut dengan mengatakan bahwa, Al-Qur'an sendiri dalam banyak ayatnya mengatakan bahwa umat Islam harus menjauhi larangan Allah Swt dan RasulNya serta mengikuti segala perintah Allah Swt dan Rasul-Nya. Perintah dan larangan Rasulullah SAW ini hanya dapat diketahui setelah ia wafat, melalui hadis-hadisnya. Dengan demikian landasan utama bagi otoritas hadis-hadis

${ }^{14}$ M. Alfatih Suryadilaga. Edt., Studi Kitab Hadis, 288. 
sebagai hujah dan sumber ajaran Islam kedua adalah ayat Al-Dari ketiga argumentasi ini mereka menolak otoritas hadis-hadis Rasulullah SAW sebagai hujah dan sumber kedua ajaran Islam. Dengan demikian, dalam prinsip mereka sunah tidak perlu ditaati dan diamalkan. Sumber satu-satunya ajaran Islam bagi mereka adalah Al-Qur'an.

Imam Syafi'i memberikan jawaban atas argumen-argumen kelompok inkarsunah tersebut dengan mengatakan bahwa:

(1) Al-Qur'an sendiri dalam banyak ayatnya mengatakan bahwa umat Islam harus menjauhi larangan Allah Swt dan Rasul- Nya serta mengikuti segala perintah Allah Swt dan Rasul-Nya. Perintah dan larangan Rasulullah saw ini hanya dapat diketahui setelah ia wafat, melalui hadis-hadisnya. Dengan demikian landas-an utama bagi otoritas hadis-hadis sebagai hujah dan sumber ajaran Islam kedua adalah ayat Al-Qur'an sendiri;

(2) dengan menguasai bahasa Arab, maka orang akan tahu bahwa AlQur'an-lah yang memerintahkan mereka untuk mengikuti su- nah Rasulullah SAW yang diriwayatkan olch peri- wayat-periwayat terpercaya (ap-padiqin). Pernyata- an ayat untuk mongikuti sunah Rasulullah SAW sama halaya dengan perintah mengikuti Al-Qur'an. Dalam hal ini Imam Syafi'i mengemukakan surah al- Jumu'ah ayat 2 dan surah al-Ahalb ayat 34; dan,

(3) Al-Qur'an mengandung banyak perintah atau larangan yang sifatnya umum tanpa memberikan ba- gaimana perincian pelaksanaannya. Dalam ayat- ayat yang sifatnya umum ini diperlukan pénjelasan dan perincian pclaksanaannya. Kalau tidak, maka hamba Allah Swt tidak akan dapat melaksanakan perintah atau larangan tersebut sesuai dengan kehendak Allah Swt. Di sinilah hadis-hadis Rasulullah saw berfungsi.

Kelompok kedua dari ingkar sunah adalah kelompok yang menolak hadis-hadis Rasulullah saw yang kandungannya tidak disebutkan dalam Al Qur'an, baik secara implisit maupun eksplisit. Ini berarti hadis-hadis tidak punya otoritas untuk me- ncatukan bukum baru, di luar yang disinggung AlQur'an, Argumcntasi yang dikemukakan oleh kelompok kedua ini sama seperti yang dikemukakan oleh kelompok pertama, yakni bahwa Al-Qur'an telah menjelaskan segala sesuatu yang berhubungan dengan ajaran-ajaran Islam.

Akan telapi menyimak pada bantahan-bantahan Imam Syafi'i di atas, argumen kclompok kedua ini pun akan pupus. Jika dikatakan bahwa hadishadis itu zanni karena diproses dengan jalan yang zanni, maka dari sekian banyak hadis itu ada juga yang sifatnya qat'i. Terhadap hadis yang zanni ini Imam Syafi'i juga mengatakan bahwa tidak semua hadis yang zanni tersebut dapat dijadikan hujah, kecuali kalau hadis-hadis tersebut memenuhi persyaratan hadis sahih atau hadis hasan. Kekeliruan dan kesalahan dalam periwayatan sebagian hadis tidak bisa dijadikan sebagai argumentasi untuk menolak otoritas hadis sebagai hujah dan sumber ajaran Islam kedua setelah Al-Qur'an.

Argumen Imam Syafi'i tersebut telah berhasil membendung gerakan inkarsunah untuk kurun waktu yang cukup panjang, karena sejak saat itu tidak pernah lagi tercatat dalam sejarah adanya inkarsunah, kecuali pada akhir abad ke-19 dan abad ke-20. Oleh karenanya dalam sejarah Islam dikenal dua bentuk pemunculan gerakan inkarsunnah nah ini, yakni yang dikenal dengan 
inkarsunah tempo dulu (munkiras-sunnah qadim) dan inkarsunah abad modern (munkir as-sunnah hadis).

Ingkar sunnah di zaman Imam Syafi'i tersebut sukar untuk diidentifikasi, karena Imam Syafi'i sendiri tidak menjelaskan siapa lawan diskusinya tersebut. Namun, Khudari Bek (seorang ahli usul fikih Mesir) mempunyai asumsi bahwa inkarsunah di zaman Imam Syafi'i adalah dari kalangan teolog Muktazilah. Asumsi Khudari ini muncul berdasarkan isyarat Imam Syafi'i sendiri yang menunjukkan bahwa mereka itu dari Basra. Sebagaimana diketahui dalam sejarah, Basra ketika itu merupakan pusat kegiatan ilmiah yang menyangkut ilmu kalam (teologi). Dari kota Basra inilah berkembang paham dari tokoh-tokoh Muktazilah. Dalam sejarah, tokoh-tokoh Muktazilah dikenal sebagai yang banyak mengkritik Ahlulhadis (orang-orang yang dalam menetapkan hukum hanya berpegang pada Al-Qur'an dan hadis, tidak mau melakukan ijtihad).

Imam Syafi'i dalam menjaga keotentikan daripada sunnah nabi saw selalu berlandaskan pada ayat-ayat Al-Qur'an. Seperti disebutkan, dan apa yang dilarangnya bagimu maka tingglkanlah..." (QS.59:7), "Dan taatilah Allah dan Rasul, supaya kamu diberi rahmat” (QS.3:132) “...maka hendaklah orangorang yang menyalahi perintah-Nya takut akan ditimpa cobaan Ulama-ulama yang menempatkan kedudukan hadis pada tingkat kedua setelah Al-Qur'an mendasarkan pendiriannya atas dalil-dalil Al-Qur'an yang artinya: “...Apa yang diberikan Rasul kepada-mu maka terimalah dia. dan ditimpa azab yang pedih" (QS.24:63), dan "Dan tidaklah patut bagi laki-laki yang mukmin dan tidak (pula) bagi perempuan yang mukmin, apabila Allah dan Rasul-Nya telah menetapkan suatu ketetapan, akan ada bagi mereka pilihann (yang lain) tentang urusan mereka. Dan barangsiapa mendurhakai Allah dan Rasul-Nya maka sungguhlah dia telah sesat, sesat yang nyata" (QS.33:36).

Selain itu, para ulama juga mengemukakan alasan-alasan berikut; (1) Al-Qur'an diterima dengan jalan yang yakin atau maqtu'bih, sedangkan hadis dengan jalan zan (syak atau curiga) atau maznunbih. (2) Hadis adakalanya menerangkan yang diijmalkan (diringkas) oleh Al-Qur'an, mensyarah AlQur'an, dan adakalanya mendatangkan apa yang belum didatangkan oleh AlQur'an. (3) Hadis sendiri menunjuk pada fungsinya yang demikian itu. Dalam hal ini biasanya dikemukakan hadis yang diriwayatkan oleh Abu Dawud dan at-Tirmizi mengenai Mu'az bin Jabal yang diutus oleh Nabi SAW ke Yaman. Nabi SAW bertanya kepada Mu'az dengan apa ia memutuskan perkara. Oleh Mu'az dijawab: "Dengan kitab Allah." Jika dalam Al-Qur'an hukum tersebut tidak dikemukakan, maka oleh Mu'az dijawab: "Dengan sunah Rasul." Di samping itu, argumen-argumen logika dan pikiran digunakan pula oleh para ulama untuk menetapkan kewajiban menaati hadis Nabi SAW serta mendudukkannya pada tingkat kedua sebagai sumber hukum sesudah AlQur'an. ${ }^{15}$

Kelompok ketiga, kelompok yang hanya menenrima hadis-hadis mutawatir sebagai hujjah dan menolak kehujjahan hadis-hadis ahad. Sekalipun ada di antara hadis-hadis ahad itu yang memenuhi syarat sebagai hadis sahih.

15 Tim Redaksi Ensiklopdi Islam, Ensiklopedi Islam Juz. 2 (Cet. 1; Jakarta: Ichtiar Baru Van hoeve, 2000), h. 224. 
Alas an mereka, hadis ahad bernilai zanny. Artinya, proses penukilannya tidak dapat diyakini. Dengan demikian, kebenarannya sebagai yang bersumber langsung dari Rasulullah saw tidak dapat diyakini sebagaimana halnya hadis mutawatir. Padahal urusan agama harus didasarkan pada dalil-dalil yang pasti (qat'i). dalil yang pasti diterima semua umat Islam hanya Al-Qur'an dan hadis-hadis mutawatir. Selain alasan di atas, mereka juga mengemukakan ayat-ayat Al-Qur'an. Seperti: Dan janganlah kamu mengikuti apa yang kamu tidak mempunyai pengetahuan tentangnya (Q.S. 17:36). Menurut kelompok ini, bahwa ayat tersebut melarang mengamalkan sesuatu amalan yang tidak diketahui secara pasti tentang amalan tersebut. Berdasarkan ayat ini, amalan yang dikandung oleh hadis ahad tidak boleh diamalkan karena hadis ini tidak menghasilkan ilmu pengetahuan (keyakinan).

Imam Syafi'i, sebagaimana ulama lainnya, mengakui bahwa memang hadis-hadis ahad tersebut bernilai zanny karena proses periwayatannya bias saja mengalami kekeliruan dan kesalahan. Oleh karena itu, tidak semua hadis ahad dapat dijadikan hujjah, kecuali yang memenuhi persyaratan sahih atau hasan. Berkaitan dengan itu, pandangan yang menolak otoritas kehujjahan hadis-hadis ahad secara keseluruhan adalah keliru dan tidak benar. Alasan lain yang ikemukakan Imam Syafi'i adalah dengan menganalogikan haids ahad dengan dua orang saksi sebagai alat bukti. Kesaksian dua orang yang memberitahukan bahwa seseorang telah membunuh orang lain dapat diterima. Pembertiaan seperti itu bersifat zanny. ${ }^{16}$

Dari tiga kelompok yang menjadi sorotan Imam Syafi'i tentang posisi dan keberadaan dari paham ingkar sunnah, secara ilmu pengetahuan memberikan sebuah sumbangsih pemikiran yang positif bahwa ingkar sunnah tidak semua pengikut yang ada di dalmnya, menolak secara keseluruhan sunnah Rasulullah saw sebagai sumber kedua setelah Al-Qur'an sebagai firman Allah Swt. Dalam hal ini, memahami sebuah kelompok atau paham dalam ajaran Islam, unsure history atau sejarah sangatlah urgen untuk diperhatikan dengan valid, supaya analisis yang dikemukakan betul-betul objektif dan dapat diakui kebenarannya secara ilmiah. Dan apa yang disumbangkan oleh pemikiran Imam Syafi'i tentang Ingkar sunnah dapatlah dijadikan landasan dalam berpikir yang baik dan benar.

\section{III.PENUTUP}

Ingkar sunnah merupakan sebuah paham atau pendapat yang berasal dari orang-perorangan atau paham yang berasal dari satu kelompok, bukan gerakan atau aliran. Karena, ingkar sunnah adalah satu golongan yang meragukan tentang kehujjahan dan menolak hadis sebagai sumber hokum kedua setelah Al-Qur'an dalam menjalankan syariat Islam. Dalam hal ini. Pahan ingkar sunnah tersebut timbul pada sebagaian minoritas umat Islam yang menolak dasar hokum dari sunnah shaih, baik sunnah praktis atau yang secara formal dikodifikasikan para ulama, baik secara totalitas mutawatir maupun ahad atau sebagain saja, tanpa ada alas an yang dapat diterima.

${ }^{16}$ Abdul Azis Dahlan Edit., Ensiklopedi Hukum Islam Juz. 3 (Cet. I; Jakarta: Ichtiar Baru Van Hoeve, 2002), h.726. 
Ingkar sunnah dalam sorotan Imam Syafi' i, menurutnya terdiri dari beberapa bebntuk pemahaman. Ada ingkar sunnah ekstrim dan ada inkgar sunnah yang moderat. Ingkar sunnah ekstrim adalah ingkar sunnah yang menolak sunnah secara keseluruhan dengan argument bahwa Al-Qur'an adalah kitab suci yang berbahasa arab yang sudah dipahami oleh orang arab sendiri uslub-uslubnya, karena tidak perlu lagi penjelasan melalui sunnah. Sedangkan ingkar sunnah yang moderat adalah tetap menerima sunnah tetapi sunnah yang berkwalitas mutawatir. Dalam hal ini yang ditolak adalah sunnah yang berstatus ahad dengan alas an bahwa hadis ahad tingkatannya hanya sampai pada yang zany (samar-samar atau tidak jelas), ada kemungkinan perawi hadis ahad tersebut lupa atau berbuat salah.

Pada dasarnya, bentuk pemikiran yang dibawa oleh ingkar sunnah secara umum banyak dipengaruhi oleh pemikiran yunani yang lebih mengedepankan logika, dan juga adanya lara belakang ilmu pengetahuan tentang hadis dan ulumul hadis yang masih minim. Tetapi pada sisi yang lain, pemahaman yang dibawa oleh ingkar sunnah, secara logika memiliki sisi positif yang berlandaskan pada pendapat Imam Syafi'i. Dan juga dibarengi dengan menggunakan argumentasi yang baik dan benar. Khususnya ingkar sunnah yang tetap menerima hadis yang berkwalitas hadis mutawatir. Dan hal ini juga memberikan satu pemahaman untuk senantiasa dan selalu hati-hati menggunakan hadis-hadis yang memiliki kwalitas hadis ahad.

\section{DAFTAR PUSTAKA}

Anis, Ibrahim. Al-Mu'jan Al-Wasith, Juz. 3. Mesir: Darul Ma'arif, 1972.

Dahlan, Abdul Azis. Edit., Ensiklopedi Hukum Islam Juz. 3. Cet. I; Jakarta: Ichtiar Baru Van Hoeve, 2002.

Ichwan, Mohammad Nor. Studi Ilmu Hadis. Cet. I; Semarang: Rasail, 2007.

Ismail, M. Syuhudi. Hadis Menurut Pembela, Pengingkar dan Pemalsuannya. Cet. I; Jakarta: Gema Insani Press. 1995.

Jawas, Yazid bin Abdul Kadir. Kedudukan Assunnah Dalam Syariat Islam. Cet. 6; Bogor: At-Taqwa. 2015.

Khon, Abdul Majid. Pemikiran Ingkar Sunnah. Cet. I; Jakarta: Bulan Bintang, 2000.

Hadis Tarbawi; Hadis-Hadis Pendidikan. Cet. I; Jakarta: Kencana Prenada Media Group. 2012.

Ulumul Hadis. Cet. 4; Jakarta: Amzah, 2016. 
Qordhowi, Yusuf. Al-Madkhal li Dirasah As-Sunnah Al-Nabawiyyah, diterjemahkan oleh Agus Suyadi Raharusun dan Dede Rodin, dengan judul Pengantar Studi Hadis. Cet. I; Bandung: Pustaka Setia, 2007.

Suryadilaga, M. Alfatih. Aplikasi Penelitian Hadis Dari Teks ke Kontek. (Cet. I; Yogyakarta: Kalimedia, 2016.

dkk, Ulumul Hadis. Cet. I; Yogayakarta: Kalimedia, 2015.

--------. Studi Kitab Hadis. Cet. I; Yogyakarta: Teras. 2003.

Syakir, Ahmad Muhammad. Al-Risalah lil Imam Muhammad Idris al-Syafi'i. Beirut: Darul Kutub al-Ilmiyah, t.th.

TIM IAIN Syarif Hidayatullah, Ensiklopedi Islam Indonesia. Cet. I; Jakarta: Djambatan 1992.

Tim Redaksi Ensiklopdi Islam, Ensiklopedi Islam Juz. 2. Cet. 1; Jakarta: Ichtiar Baru Van hoeve, 2000. 